\title{
Role of Leadership in Transforming the Profession of Quantity Surveying
}

George Ofori and Shamas-ur-Rehman Toor (Department of Building, National University of Singapore, Singapore)

\begin{abstract}
The construction industry is facing a period of change. The roles of the professions involved in the industry in general, and of quantity surveyors in particular, are also changing. There are opportunities for surveyors to seize the initiative to broaden their involvement in projects, and attain strategic positions within the industry. However, they will have to improve upon their skill sets and their knowledge bases. Senior quantity surveyors interviewed in Singapore shared their views on the challenges facing the construction industry, and their profession. They suggested that the quantity surveying profession would only be able to address the pressing issues it faces if it pays more attention to innovation and the development of its people. It should be able to attract and retain talent. Knowledge management will be of critical importance. This will be enabled and facilitated by knowledge leadership.
\end{abstract}

Keywords: quantity surveying, challenges, knowledge management, knowledge leadership, Singapore.

\section{INTRODUCTION: THE CHANGING FACE OF THE CONSTRUCTION INDUSTRY}

The world is changing rapidly. So are the demands on the professions, and hence the role of professionals. Organizations in all sectors of the economy are under increasing pressure to offer value added services, innovate, and learn to survive and grow in the face of increased competition and rapid change. Business enterprises are under threat from their competitors which may be able to offer superior and more comprehensive services. The changing landscape of the construction industry also demands that current practitioners as well as future professionals should be proactive to drive change instead of merely coping with developments.

The construction industry faces several technical, social, financial, political, and cultural challenges (Toor and Ofori, 2008a). These include the growing volume of construction demand and activity in many countries which is resulting in severe pressure on resources (Ofori, 2003); increased private-sector participation in infrastructure projects (Raftery et al., 1998); and lack of quality people and an ageing workforce (Songer et al., 2006). Projects are becoming bigger and more complex in nature with higher numbers of stakeholders with different intentions for the project who may have multi-ethnic and multi-cultural backgrounds (Ofori and Toor, 2009). Clients are also becoming more knowledgeable and hence more demanding and selective in what they want from consultants and to whom they award the work (Preece et al., 2003).

Consequently, there is a need for changes in many aspects of the operations of the construction industry (Ofori, 2003). There should be greater focus on how project procurement processes can be improved (Kumaraswamy and Dulaimi, 2002); how the construction value chain can be made more efficient (Atkin, 1998); how the concerns of sustainable development, health and safety in project delivery can best be addressed (Lingard and Rowlinson, 2006); how the level of professionalism in the industry can be enhanced (Vee and Skitmore, 2003); how the adversarial mindsets of practitioners can be transformed and a collaborative and partnering approach promoted (Li et al., 2001); how corruption in the industry can be eradicated (Stansbury, 2005; Transparency International, 2006); how the social image of construction can be enhanced (Rameezdeen, 2007); and perhaps above all, how to attract, retain, and develop talent (Toor and Ofori, 2008b).

The quantity surveying profession is also going through a period of rapid transformation. A profession that was considered to be facing extinction a decade ago has been revitalised, and faces a high demand for its services in the construction market in many countries (Cartlidge, 2006). There is a new optimism about the future of quantity surveying as a profession and quantity surveyors are now seen as important players in the construction industry (Smith, 2004). The trends highlighted in the preceding paragraph show that there is even greater potential for the quantity surveyor as there are many areas where innovative application of the existing skills of the surveyor, as well as judicious extension and enhancement of these skills, can result in progress in the industry.

\section{OBJECTIVES OF THE PAPER}

This aim of this paper is to explore how the leaders of the quantity surveying profession in Singapore perceive the future of their field, and the role of the quantity surveyor in the new situation in the construction industry. The objectives are:

- to review the challenges facing the construction industry in general and their implications for the quantity surveyor in particular

- to examine and evaluate recent developments in the quantity surveying profession and consider the likely future of the profession

- to consider the role of leaders in the transformation of the industry to enable it to face the future.

\section{THE CHANGING FACE OF QUANTITY SURVEYING}

Quantity surveying is not a new profession. Ever since humans have built buildings, they have found it necessary to estimate the cost of the whole endeavor, as well as the quantity of the materials that would be required. The historians suggest that the Egyptians had some systems of quantity surveying. However, the profession first developed more formally in the 17th century in the UK. Primarily, the quantity surveyor is the project cost consultant, and the adviser to the client and other members of the project team on matters relating to procurement and the contract (Fellows et al., 2003). In a contractor's organisation, the functions of the surveyor centre around cost and contract management. 
Over the last few decades, quantity surveying as a profession has gone through a number of transitions. The advent of information technology and the potential it offered, coupled with the downturn in construction activity in the UK and a number of other countries during the mid-1980s and late 1990s, and the challenges that included those discussed above, which saw even more intense competition in the construction industry with firms seeking opportunities beyond their professional domains, led many observers to predict, and many within the profession to fear, that quantity surveying might disappear as a formal profession. When Cartlidge wrote the first edition of his book 'New Aspects of Quantity Surveying Practice' in 2002, he noted that the profession was facing several challenges and people thought that it was on the verge of being extinct (Cartlidge, 2002). However, in 2006, Cartlidge noted that there was a severe shortage of quantity surveyors. He cited the survey of the Royal Bank of Scotland which found that quantity surveyors were the best paid graduate professionals in 2005 (see: Cartlidge, 2006). The reasons for the 'new' rise of the profession include increase in the volume of construction activity, growing scarcity of other construction professionals, and demand for experts in cost engineering and financial management.

\section{CHALLENGES FOR QUANTITY SURVEYORS}

The changes in the construction industry discussed above pose a number of challenges to all who work in it. They also offer business opportunities, and avenues for greater achievement. Two examples of these may now be discussed from the perspective of the quantity surveying profession. The first of these challenges is the movement for sustainability. The development and application of comprehensive assessment tools for green buildings incorporating the existing tools which focus only on the environmental aspects (such as the Green Mark in Singapore and the Leadership in Energy and Environmental Design [LEED] in the US) is an area in which quantity surveyors can play a significant role. They need to further enhance their skills, and help to develop the technologies and innovations to achieve sustainable buildings. Thus, the drive towards sustainable development offers the opportunity for quantity surveyors to go beyond their present focus on cost to provide leadership in the area of overall economic viability of constructed items, which incorporates the issue of sustainability.

Second, the many recent scandals show that the business world faces corporate malfeasances and ethical transgressions (see: Mehta, 2003; Revell, 2003; Treviño and Brown, 2004; Manz et al., 2008). Unethical leaders have been able to exploit the loopholes in management systems to fulfill their personal desires at the expense of their organisations and employees (see: Padilla et al., 2007; Schaubroeck et al., 2007). The construction industry is perceived in many countries as one of the most undesirable sectors to work for (Toor and Ofori, 2007). Transparency International (2006) found construction to be the most corrupt industrial sector. Some researchers have studied the reasons for unethical behaviour in construction. Fan et al. (2001) suggest that the increasing ethical problems in construction professions may be due to the perception gap about ethical issues between senior and relatively younger professionals.

The quantity surveyors responding to their survey ranked employer, self and client as more important when they faced any ethical dilemma. On the contrary the interest of the general public was ranked relatively low. $\mathrm{Ho}$ and $\mathrm{Ng}$ (2003) discovered a significant impact of education and experience on the attitude of quantity surveyors towards sacrificing their self-interest for the greater good. They found that more junior quantity surveyors place more emphasis on duty whereas more senior professionals are more concerned about process and consequence. As quantity surveyors are responsible for cost engineering and financial management on construction projects, they are in a strong position to help to establish higher standards of transparency and accountability. They can establish mechanisms which can ensure greater financial transparency on projects. They can use technology to integrate the cost and other relevant data to institute accountability and responsibility for all stakeholders.

These challenges call for transformation in the way quantity surveyors function. For example, Harun and Torrance (2006) suggest that quantity surveyors should not contain themselves within the traditional boundaries of cost management; they need to develop new niches, cultivate new knowledge and break into new areas in order to enhance their competitiveness. Smith (2004) suggests that there is some uncertainty about the capacity in which, and for whom, the quantity surveyor would work, and the nature of quantity surveying firms in the future. Brümmer (2004) also suggests that quantity surveyors should play a more effective and proactive role across all stages of the project life cycle. He draws attention to constantly changing procurement systems, necessitating refinement in the services that quantity surveyors offer.

The next section discusses opportunities that the quantity surveyors can exploit in order to play a more strategic role in the construction supply chain.

\section{OPPORTUNITIES FOR QUANTITY SURVEYORS}

The discussion above shows that there is a broad sentiment in the industry about the potential role that the quantity surveyors can play. MBD (2004) noted:

\section{Despite the threat of the erosion of conventional functional boundaries in the building services sector as a result of developments in information and communications technology, $M B D$ believe that there are clear opportunities for quantity surveyors to capitalise on the resources and capabilities that they have gained in order to continue to add value to customers, albeit through an increasingly professional and management function ... MBD believe that there are sufficient grounds for optimism that quantity surveyors will be able to adapt to these challenges. However, ... the potential development of the market is likely to be determined by the strategies adopted by the large surveying companies in the face of an increased threat to their traditional position.}

It has been suggested that quantity surveyors should expand their expertise to other areas relating to construction such as facilities management, arbitration, construction law, value management, construction management and project management (Harun and Torrance, 2006). Other areas that quantity surveyors can operate in include health and safety, and environmental performance (Verster, 2004), and information management (Smith, 2004). Other potential areas are e-commerce, financial risk management, supply chain management, organisational behaviour and organisational culture (Harun and Torrance, 2006).

Yin (2004) predicts a surge in market demand for construction cost professionals in China. He argues that the increase in the volume of construction works in China is likely to result in the need for more quantity surveyors. He noted that the total number of cost engineers in China was 60,000 in 2004 and that this number was increasing at an annual rate of 7,000. 
In a survey in Australia, Smith (2004) found the following: (i) the role of the quantity surveyor as an independent consultant will expand in the future; (ii) future quantity surveyors will mainly be employed as part of a professional team in multi-disciplinary practices providing integrated 'in-house' services; (iii) quantity surveyors will be key players in the construction industry in ten years time; (iv) the quantity surveying profession should be actively involved in utilising, developing and promoting the use of computer-aided design (CAD) automated quantities; and (v) greater use of information technology will enable the quantity surveying profession to provide better services to clients. Smith (2004) noted that 'fee-cutting' due to competition among the firms was an unhealthy trend. He emphasises that quantity surveying firms should maintain and develop expertise in their core competencies, invest in technology, diversify and broaden the range of services they offer, engage in continuing professional development, and learn to utilise information technology such as $\mathrm{CAD}$, while ensuring that their knowledge and techniques evolve with the key developments in the technology.

To address the issues highlighted above, the quantity surveying profession needs change leaders. The surveyors are in a position to seize these opportunities by developing new skills, establishing new niche areas for these skills, and expanding their current functional role. The profession must be bolder, more entrepreneurial and proactive. In his proposal for developing competitive strategies for quantity surveyors, Grant (2004) proposes that the surveyors should diversify their domain of expertise and strengthen the bases of their strategic assets such as education, training, experience, and knowledge.

\section{RESEARCHAPPROACH}

A total of 45 senior practitioners in the industry were interviewed out of whom 6 were senior executives and leaders in the major quantity surveying firms in Singapore (see Table 1 for demographic details). These executives were nominated as authentic leaders and successful professionals by their peers in their own professions and the industry.

The interview questions were based on the review of the literature on authentic leadership. The interviews focused on the leaders' developmental experiences and the strategies they used to influence their followers and organisations. The part of the study reported on in this paper was based on responses to the following questions: (i) the personal and professional challenges the interviewees have faced in their leadership development; (ii) what they want to achieve as leaders; and (iii) the legacy the interviewees hope to leave behind as leaders. Under the first question on personal and professional challenges, the senior surveyors interviewed discuss the issues the profession has faced.
The discussion of what they want to achieve as leaders includes consideration of opportunities for surveyors in general. Finally, the responses on the leaders' legacy also covers the changes in the construction industry in general and the surveying profession which they wished to see.

The interviews were audio-recorded, transcribed and analysed.

\section{INTERVIEW FINDINGS}

Analysis of the relevant portions of the interview transcripts results in a number of issues that leaders of major quantity surveying firms in Singapore had underscored. Some of the leaders interviewed who belonged to other professions also raise issues that are pertinent to surveyors. Some of these points are discussed in the following sections.

\section{MINDSET OF THE INDUSTRY: MAIN BASIS FOR COMPETITION}

There was general agreement among the interviewees that the construction industry, including the quantity surveying profession, is going through a period of considerable change. Most interviewees note that the mindset of the industry needed to be changed. One interviewee, while talking about the changing nature of quantity surveying and the basis of competition, notes:

The service in the old days was more easy-going. But over a period of time, procurement methods changed and the practice got more difficult and challenging. We always seemed to be doing more work for less fees. I went through three recessions, in 1976, 1986, and 1998. Each time we come out of a recession, new fee benchmarks, and new service benchmarks are set. In the recession we competed for work, and we competed on fees. Then you try to do more for the same fee. So, we were going through all these changes.

He notes further:

Then, in late 1980s and 1990s, when the developers were bidding for land and land prices were about 75 percent of the development cost, we looked at other methods to procure building contracts quickly in order to build faster... It has always been very challenging in that sense, because when developers pay hundreds of millions of dollars for the land, ... the interest is very high. So the timetable is always tight. So it has been getting more challenging, year after year.

On a broader front, the interviewees also highlight the need for: greater levels of professionalism in the industry; the need for the industry to consider adopting manufacturing processes in its operations; and the need for innovation in construction methods.

Table 1: Demographic details of subjects

\begin{tabular}{llll}
\hline Interview & Gender & $\begin{array}{l}\text { Industry } \\
\text { Experience }\end{array}$ & $\begin{array}{l}\text { Position in the } \\
\text { Organisation }\end{array}$ \\
\hline A & Male & Over 30 years & Executive Chairman \\
B & Male & Over 10 years & Executive Director \\
C & Male & Over 15 years & Director \\
D & Female & Over 10 years & Director \\
E & Male & Over 25 years & Managing Director \\
F & Male & Over 25 years & Managing Partner \\
\hline
\end{tabular}


One of the interviewees expressed his desire for construction professionals to be given more time to achieve quality in their work. He observes:

I wish people are given more time to do their jobs better ... That's really something we need ... there is no quality of work or quality of life. That is the saddest thing of our industry. Our clients take years to decide to build and to develop a project. The moment they decide, they want to finish it yesterday ... Everybody is working during the night. If you're working so late, could there be quality of work? It can never be so because you are just rushing to finish the work ... in the UK, it's a lot different; people have more time to think, more time to plan. But I think the work has changed, now everything is superspeed - because of computers, because of the internet ... I remember in the UK, our site meetings used to be once a month. Here in Singapore, there is a site meeting every week. Thus, every week, our quantity surveyors will go to the site ... and sometimes twice a week. They just want to go through the minutes of the meeting; ... and this is ridiculous ... Due to these deadlines and short schedules, we are taxed. I wish we get more time to accomplish quality work.

\section{THE HUMAN RESOURCE CHALLENGE}

From the discussion of the interview findings in the preceding section, it is clear that quantity surveyors in Singapore are facing growing pressure to perform more for smaller compensation. Although this trend has led to unhealthy competition among the firms, it has also motivated them to offer new services and pursue innovation to be competitive in the market. One adverse consequence of fee-based competition is its effect on compensation packages in the profession. A senior executive in a leading quantity surveying firm highlighted the issues of scarcity of human resources due to unattractive salaries in the quantity surveying profession. He observes:

We have problems getting people to do the quantity surveying work now. Staff come and go, which is also a problem. And all this affects the field. We cannot pay our staff very well so they go somewhere else. Comparatively, lawyers, doctors, accountants and even architects get more pay. With the amount of work that we do, we deserve to get more actually. So this is something we hope we can change, but it is very difficult. The government is having this pro-competitive air, opening up the market. All this will press the field down. This is a general issue for the whole industry.

Some interviewees showed their concern about the shortage of young graduates in quantity surveying. One interviewee observes:

My main concern is with the lack of skills and talents in Asia. Traditionally, we had to rely on UK and Australia which, understandably, have higher proportions of graduates in the market. Here, there are very few, and the industry here is booming, burgeoning all over. So, our struggle has always been to get the right people at the various levels in the firm because we need to see a structure to move up as well, and this has been very, very difficult. It is even worse now, because of the huge demand for construction work in the Middle East, China and Singapore now. So that has been our main worry.

Another interviewee emphasised the importance of human resource management and development to his firm. He says:

I want to go more into HR; how to retain staff and motivate them. To improve and elevate ourselves to provide more value services to our clients.
The interviewees highlight the need to change the mindsets of young professionals. They note that many ambitious young professionals are not willing to climb the ladder of their careers, but quickly want to take up senior management positions. One interviewee observes:

Every year, we employ NUS (National University of Singapore) graduates and it takes a long time for us to really change their mindset of how we expect them to deliver our services. It is not their fault. Firstly they do not have the experience. They only have some knowledge but they do not know how to undertake work in practice, using this knowledge, so we have to teach them. Secondly, a lot of them are undecided whether this is the place for them. They just want to try it out for two years .... and during this period, that is when many disappointments arise; disappointments from us, from clients, from themselves.

You see, if a student walks into this office and is determined that 'I want to be the best quantity surveyor and I want to serve this firm', it is a totally different attitude from a guy who walks in [thinking] 'let me look-see, what they have to offer, see whether this profession is for me'... I have only had one employer in my whole life ... so I am very loyal; I want to serve this firm. But I don't get that commitment from the staff, and this is the greatest challenge.

I would say $50 \%$ of them leave because of disappointment; their expectations are not met. You see, it is the chicken and egg situation now. How can I let you do something that you like when I don't even trust you yet? How can I say I will let you do this job, or let you meet this client when I am still having problems with you doing the fundamental things? They get disappointed because the fundamental things they have to do are so boring, so mundane. [They think] 'I am trained for higher things', 'I want to be the leader', 'I am not going to measure doors', 'it is the most boring thing' etc ... This is a problem, but there is nothing you can do; the young people have their own minds.

This detailed description of the attitude of young professionals shows that the organisations have to work hard to attract, develop and retain fresh blood. Describing this as a big challenge, one interviewee notes:

A lot of companies, especially the large international firms, tend to have very short-term policies in terms of retention of talent within the firm. So I think that is one area that is very important ... The question is not technology. You can get all the best PCs (personal computers) and whatever, best software, but it is actually the people [who do the job]. So the question is how do you get the best people, and how do you retain the talent, and how do you groom the talent as the next generation of leaders.

\section{NEED FOR INNOVATION}

The fee-based competition among professional quantity surveying firms also militates against their efforts to accumulate resources to support research and innovation in the firms. The Executive Director of one quantity surveying firm stressed the need for innovation in the construction process. He observes that it is important to change the industry's mindset regarding the basis for competition, and that clients should be willing to pay for innovation. He notes:

As far as the industry is concerned, it is hard to see an improvement. We have many smaller firms with 5 to 10 employees. They charge very, very low fees to survive. In our case [the bigger firms] the developers don't pay for the R\&D 
we do. They just want to get the job done. So long as you have developers who still do not see the light and encourage $R \& D$, I don't see the change coming in the construction industry. In smaller firms with 10 staff, they work from home and use cheaper software and their overheads are so low. We do R\&D and we have bigger overheads. There is a difference, you see, but the clients are not ready to pay for this. If they are not ready to pay for this, then I don't see the industry growing.

Another interviewee spoke about the need for investment in research and innovation. He observes:

I think the construction industry in Singapore is a very big dinosaur in terms of technology usage, construction methodology, usage of equipment, and related construction skills. The industry has tried a lot of things from modular design to pre-cast usage. Some incentives have also been given by the government, and clients, for example, to promote quality. But the bottom line is actually the dollars and cents for contractors and developers. It's largely because of the recession in the industry over the last few years as firms do not have funds to invest in the new technology and the development of new skill sets. With more money these days, as the industry is in a boom, more can be spent on $R \& D$, and invested in developing the skill sets of our people, and in human resource training. Now is the time, and we should ensure that we take the necessary measures to benefit from it.

\section{KNOWLEDGE LEADERSHIP}

Knowledge leadership also emerges as an important topic in the interviews. Leaders of quantity surveying firms highlight the importance of knowledge in the competitive business world. They also emphasise the importance of leadership to drive the effective management and appropriate application of knowledge. An Executive Director spoke about the efforts he had made in building the knowledge management system within his organisation. He says:

...I came up with knowledge management. Knowledge in the office should be retained. If a person goes, knowledge goes with him. So we retain the knowledge...

A senior executive in a large quantity surveying firm notes the importance of knowledge and its management:

...we have the university graduates and polytechnic graduates. As we move with knowledge management into the future to do business, this difference [between university and polytechnic graduates] may actually become no difference at all. Because these graduates from the polytechnic are doing just as well with knowledge management as the university graduates. This is going to change our business. Take that further, I project the value add of our staff, in terms of skills, in future is going to be more than what value they are to us now. In the time to come, with this huge data base of knowledge management on so many areas, ... you will find that even those from the polytechnics are going to come out just as [good], with knowledge ... Actually, this knowledge management and information is very important, but people don't realise it ... I see it happening, that's why I spent time building it up.

Some of the leaders interviewed also expressed the need for sharing knowledge across the industry. They draw attention to the willingness of the leader to look beyond the traditional narrow perception of knowledge management as providing competitive advantage for the firm. One interviewee highlights the importance of sharing knowledge:
Many would say ... 'why do you teach your competitors?' But people do not realise that the more you do, it will be better for you. Because people see you as a leader, as a provider of information, they look at you differently from the rest. I think very differently, and I have a very positive response from the industry, from the community, from my fellow professionals. And they have always helped me in return, when I have difficulties, when I approach them.

These views underscore the need for a culture of knowledgesharing and knowledge-caring in which professionals are willing to learn from others as well as share their experiences and knowledge with others.

\section{OTHER ISSUES}

The interviewees highlight several other issues. First, they are concerned about the recognition of quantity surveying as an established profession. A senior executive in a quantity surveying firm notes that:

I hope our profession will be accepted and recognised more by the industry and everybody. Because not many people know about quantity surveying and they don't know what the quantity surveyor does. We have problems attracting people to come and study and join the profession as quantity surveyors.

Another interviewee underscored the importance of skills and the need to adopt IT tools. He says:

One part of the picture is the fees and the other part is how you do your work. You put in investments and efforts to make yourself more productive. If you become more productive, the fees you get will be comparatively higher. So computerisation is something we pay a lot of attention to in our firm, in our work as quantity surveyors ... and we have all these IT tools to help us do more ... to improve the processes.

\section{DISCUSSION}

Quantity surveying is a knowledge-intensive profession. In such a field, competitiveness depends on how its practitioners generate, retain, and successfully apply knowledge (Lengnick-Hall and Lengnick-Hall, 2003; Kearns and Lederer, 2003). Knowledge is now becoming a defining characteristic of economic activities, as opposed to tangibles such as goods, services or production processes. Some researchers even consider knowledge as the new capital resource that offers better leverage as compared to financial investment (Harun and Torrance, 2006). Companies need to organise their knowledge (Davenport and Prusak, 1998) in order to enhance their effectiveness (Cummings, 2004). Many researchers argue that knowledge management is crucial for the effective performance of organisations (Davenport and Prusak, 1998; Sabherwal and Becerra-Fernandez, 2003), and that it is also an important factor in organisational success (Quintas, 2002).

Some researchers have warned that it is a mistake to relate knowledge management to only the development of information and communication technology tools or infrastructure (Yahya and Goh, 2002). Knowledge management makes a difference to the performance of the organisation only when people are willing to use the information and data it provides, and are committed to exploring its full potential (van Winkelen, 2006). Huang et al. (2008) suggest that knowledge sharing is a human act, and therefore, voluntary and discretionary in nature. It can be encouraged and motivated but not mandated. In this sense, it is suggested that the consideration should transcend knowledge 
management, and focus on 'knowledge leadership' (see, for example, Kaplan and Reed, 2007).

Leaders who are able to drive knowledge management effectively and get more of the employees of their organisations to apply the resources it provides are termed "knowledge leaders" (Singh, 2008; Viitala, 2004; Lakshman, 2005). Skyrme (2000), among the first to use the term "knowledge leadership", argued that knowledge leadership constantly promotes the development and innovation of organisational resources such as information, individual skills, knowledge, and learning networks. Knowledge leaders do not only set an example and inspire vision for knowledge sharing (Alvesson and Sveningsson, 2003), but they are also instrumental in modelling good practices, coaching and mentoring others (Debowski, 2006), and providing resources for an adequate technological infrastructure and a supportive environment in which knowledge management can flourish.

Knowledge leadership is a vital factor that can drive the future of quantity surveying as a profession. As knowledge leaders, future quantity surveyors will need to take the responsibility to explain the needs, objectives, and goals of knowledge management within their own firms as well as across the industry. They will need to invest in human and social capital in order to establish relationships and networks that will help them to drive the construction industry towards a knowledge-sharing future. They will need to empower their employees and offer them opportunities for growth and development.

The leaders interviewed also want to see significant changes in the way the construction industry in Singapore operates. A common aspiration of the interviewees is a desire for a high level of professionalism in the industry. They wish to see changes in the practices, relationships and overall culture of the construction industry in Singapore, especially the main bases for competition. The responses of the interviewees indicate that there is a strong desire for change among the industry's leaders. This bodes well for the future of the construction industry in this country.

Finally, as Toor and Ofori (2008b) propose, a concerted effort by the academic institutions, industry, professional bodies and government agencies is essential to produce professionals who are adequately equipped to deal with the challenges of their fields in the 21 st Century. With such concerted effort, quantity surveying education can be transformed to meet the needs that various authors have highlighted (see, for example, Harun and Torrance, 2006). A holistic range of courses - including, but not limited to, facilities management, arbitration, sustainability, information management, professional practice, entrepreneurship and organisational behaviour - can to help prepare quantity surveyors of the future. (see, for example, Smith, 2004; Verster, 2004; Harun and Torrance, 2006). The collaborative initiatives can also include structured mentoring schemes, internships, joint research and involvement of professional bodies in the delivery of particular modules such as professional practice. Government agencies can provide a catalyst of the whole process through funding, changes in regulations and other forms of support.

The empirical study presented in this paper was conducted in Singapore. However, the majority of the respondents were senior practitioners who were exposed to the international market. They mostly speak in the global context while discussing the transformation of the profession. It is pertinent to note that the sentiments of the construction leaders in Singapore about the QS profession are not much different from other views on the profession that have been identified elsewhere in the world (see, for example, Harun and Torrance, 2006; Yin, 2004; Smith, 2004).
Therefore, the findings in this paper are not only useful for QS professionals in Singapore, but are also relevant and valuable to professionals from other countries.

\section{CONCLUSION}

The profession of quantity surveying has been revitalised during the last few years. Growing demand for construction and changes in the industry and the construction process offer both challenges and opportunities. They make it necessary for quantity surveyors to redefine their role. Some of the key trends include the greater level of sophistication in the demands posed by, and expectations of, clients, users, and the community at large. Considering the prevailing and future challenges and opportunities, quantity surveying can be seen as a profession at an important cross-roads from which it can go beyond its traditional cost engineering and financial management roles and use its core competencies to assume a leadership role in the industry. For example, the quantity surveying profession can promote integration of the construction supply chain by developing niches in procurement, contract management and arbitration, facilities management, life-cycle costing, and sustainable development. In order to realise this and other potentially beneficial initiatives, the quantity surveying profession needs leaders to drive the effort towards exploiting the opportunities. Quantity surveyors have the potential to emerge as knowledge leaders in the construction industry.

\section{REFERENCES}

Alvesson, M. and S. Sveningsson (2003) 'Good visions, bad micromanagement and ugly ambiguity: Contradictions of (non)leadership in a knowledge-intensive organization', Organization Studies, 24(6), 961-988.

Atkin, B. (1998) 'Unravelling the value chain in construction', in proceedings of $6^{\text {th }}$ Conference. International Group for Lean Construction, Cuaruja, Brazil.

Brümmer, D.G. (2004) 'Challenges in quantity surveying in South Africa: Procuring the future', in proceedings of International Cost Engineering Council $4^{\text {th }}$ World Congress, (Ed.) Association of South African Quantity Surveyors, Cape Town, South Africa.

Cartlidge D. (2002) New aspects of quantity surveying practice ( $1^{\text {st }}$ Edition), London: Butterworth-Heinemann.

Cartlidge, D. (2006) New aspects of quantity surveying practice ( $2^{\text {nd }}$ Edition), London: Butterworth-Heinemann.

Cummings, J. (2004) 'Work groups, structural diversity, and knowledge sharing in a global organization', Management Science, 50(3), 352-364.

Davenport, T.H. and Prusak, L. (1998) Working knowledge: How organizations manage what they know, Boston: Harvard Business School Press.

Debowski, S. (2006) Knowledge management, Sydney: Wiley.

Fan, L.C.N., Ho, C.M.F. and Ng, V C.W. (2001), 'A study of quantity surveyors' ethical behaviour', Construction Management and Economics, 19(1), 19-36.

Fellows, R., Liu, A. and Fong, C.M. (2003) 'Leadership style and power relations in quantity surveying in Hong Kong', Construction Management and Economics, 21(8), 809-18. 
Grant, M. (2004) 'Competitive strategies for the professional quantity surveyor in South Africa', in proceedings of International Cost Engineering Council $4^{\text {th }}$ World Congress, (ed.) Association of South African Quantity Surveyors, Cape Town, South Africa.

Harun, H. and Torrance, J.V.A. (2006) 'Drivers of change: New challenges for the quantity surveyors', in proceedings of the International Conference on Construction Industry 2006: Toward Innovative Approach in Construction and Property Development, Kuala Lumpur, Malaysia.

Ho, M.F.C. and Ng, C.W.V. (2003) 'Quantity surveyors' background and training, and their ethical concepts, conceptions and interests considerations', Construction Management and Economics, 21, 43-67.

Huang, Q.V., Davison, R.M., Liu, H.F. and Gu, J.B. (2008) 'The impact of leadership style on knowledge sharing intentions in China', Journal of Global Information Management, 16(4), 67-91.

Kaplan, W.S. and Reed, A.F.T. (2007) 'KM: from concept to theory to practice: Knowledge leadership at Acquisition Solutions, Inc.', The Journal of Information and Knowledge Management Systems, 37(2), 219-232.

Kearns, G.S. and Lederer, A.L. (2003) 'A resource-based view of strategic IT alignment: How knowledge sharing creates competitive advantage', Decision Sciences, 34(1), 1-29.

Kumaraswamy, M. and Dulaimi, M. (2002) 'Empowering innovative improvements through creative construction procurement', Engineering Construction and Architectural Management, 8(5-6), 325-334.

Lakshman, C. (2005) 'Top executive knowledge leadership: Managing knowledge to lead change at General Electric', Journal of Change Management, 5(4), 429-446.

Lengnick-Hall, M.L. and Lengnick-Hall, C.A. (2003) Human resource management in the knowledge economy: New challenges, new roles, new capabilities, San Francisco: BerrettKoehler.

Li, H., Cheng, E.W.L., Love, P.E.D. and Irani, Z. (2001) 'Cooperative benchmarking: $A$ tool for partnering excellence in construction', International Journal of Project Management, 19(3), 171-179.

Lingard, H. and Rowlinson, S.M. (2006) Occupational health and safety in construction project management, London: Taylor and Francis.

Manz, C.C. Anand, V., Joshi, M. and Manz, K.P. (2008) 'Emerging paradoxes in executive leadership: A theoretical interpretation of the tensions between corruption and virtuous values', The Leadership Quarterly, 19, 385-392.

MBD (2004) 'Press Release: UK Quantity Surveyors Market Research Report', Market Business Development, August, available at: http://www.mbdltd.co.uk/Press-Release/QuantitySurveyors.htm.

Mehta, S. (2003) 'MCl: Is being good good enough?', Fortune, 27, 117-124.
Ofori, G. (2003) 'Frameworks for analysing international construction', Construction Management and Economics, 21(4), 379-391.

Ofori, G. and Toor, S.R. (2009) 'Research on cross-cultural leadership and management in construction: A review and directions for future research', Construction Management and Economics, 27(2), 119-133.

Padilla, A., Hogan, R. and Kaiser, R.B. (2007) 'The toxic triangle: Destructive leaders, susceptible followers, and conducive environments', The Leadership Quarterly, 18, 176-194.

Preece, C.N., Moodley, K. and Smith, P. (2003) Construction business development: Meeting new challenges, seeking opportunity, London: Butterworth Heinemann.

Quintas, P.R. (2002) Implications of the division of knowledge for innovation in networks, Alliances, Networks and Partnerships in the Innovation Process, Ottawa: US National Science Foundation and Statistics Canada.

Raftery, J., Pasadilla, B., Chiang, Y.H., Hui, E.C.M. and Tang, B.S. (1998) 'Globalization and construction industry development: implications of recent developments in the construction sector in Asia', Construction Management and Economics, 16(6), 729-737.

Rameezdeen, R. (2007) 'Image of the construction industry', in M. Sexton, K. Kähkönen and S. Lu (eds.), CIB Priority Theme: Revaluing Construction, A w065 'Organization and Management of Construction' Perspective, CIB Publication 313, ISBN: 978-906363-053-9, 76-87.

Revell, J. (2003). 'The Wres that won't go out', Fortune, 13, 139.

Sabherwal, R. and Becerra-Fernandez, I. (2003) 'An empirical study of the effect of knowledge management processes at individual, group, and organizational levels', Decision Sciences, 34(2), 225-261.

Schaubroeck, J., Walumbwa, F.O., Ganster, D.C. and Kepes, S. (2007) 'Destructive leader traits and the neutralizing influence of an "enriched" job', The Leadership Quarterly, 18, 236-251.

Singh, S.K. (2008) 'Role of leadership in knowledge management: A study', Journal of Knowledge Management, 12(4), 3-15.

Skyrme, D. (2000) 'Developing a knowledge strategy: From management to leadership', in D. Morey and B. Thuraisingham (eds.), Knowledge management: Classic and contemporary works, Cambridge, Massachusetts: MIT Press.

Smith, P. (2004) 'Trends in the Australian quantity surveying profession', International Roundup, 19(1), 1-15, available at: http:// www.icoste.org/Roundup1204/smith.pdf\#../Roundup1204/smith. pdf.

Songer, A., Chinowsky, P. and Butler, C. (2006) 'Emotional intelligence and leadership behavior in construction executives', in proceedings of $2^{\text {nd }}$ Specialty Conference on Leadership and management in Construction, 248-258.

Stansbury, N. (2005) 'Exposing the foundations of corruption in construction: Global Corruption Report', Transparency International, available at: www.transparency.org. 
Toor, S.R. and Ofori, G. (2007) 'Ethics and authenticity of leadership in the construction industry', in T.C. Haupt and R. Milford (eds.), proceedings of CIB World Building Congress on 'Construction for development', 14-18 May, Cape Town, South Africa.

Toor, S.R. and Ofori, G. (2008a) 'Leadership in the construction industry: Agenda for authentic leadership', International Journal of Project Management, 26(6), 620-630.

Toor, S.R. and Ofori, G. (2008b) 'Developing construction professionals of the $21^{\text {st }}$ century: Renewed vision for leadership', Journal of Professional Issues in Engineering Education and Practice, 134(3), 279-286.

Transparency International (2006) 'Preventing corruption on construction projects: Risk assessment and proposed actions for funders', available at: www.transparency.org/content/ download/2228/13048/file/2_TI-ACF_Report_Risk_Assessment_ Funders.pdf.

Treviño, L.K., and Brown, M.E. (2004) 'Managing to be ethical: Debunking five business ethics myths', Academy of Management Executive, 18, 69-81.

van Winkelen, C. (2006) 'The many faces of knowledge leadership', Knowledge Management Review, 9(1), 24-27.

Vee, C. and Skitmore, M. (2003) 'Professional ethics in the construction industry', Engineering Construction and Architectural Management, 10(2), 117-27.

Verster, J.J.P. (2004) 'Internationalisation of skills, competencies and quality service by cost engineers, quantity surveyors and project managers', International Roundup, 19(1), available at: www.icoste.org/roundup1204/Verster.pdf.

Viitala, R. (2004) 'Towards knowledge leadership', Leadership and Organization Development Journal, 25(6), 528-544.

Yahya, S. and Goh, W. (2002) 'Managing human resources toward achieving knowledge management', Journal of Knowledge Management, 6(5), 457-468.

Yin, Y.L. (2004) 'Latest developments in the cost engineering profession and higher education in Mainland China', International Roundup, 19(1), available at: http://www.icoste.org/Roundup1204/ Yin.pdf\#../Roundup1204/Yin.pdf. 